\title{
Pharmace utical and Biomedical Research
}

\section{Citrus aurantium $L$. peel extract mitigates hexavalent chromium-induced oxidative stress and cardiotoxicity in adult rats}

\author{
Mariem Chaâbane $^{1 *}$, Awatef Elwej ${ }^{1 \#}$, Imen Ghorbel $^{1 \#}$, Tahia Boudawara ${ }^{2}$, Najiba Zeghal $^{1}$, Nejla Soudani ${ }^{1,3}$ \\ ${ }^{1}$ Animal Physiology Laboratory, Department of Life Sciences, Sciences Faculty of Sfax, University of Sfax, BP 1171, 3000 Sfax, Tunisia \\ ${ }^{2}$ Hist opathology Laboratory, University of Sfax, CHU Habib Bourguiba, 3029 Sfax, Tunisia \\ ${ }^{3}$ Unit of Physiology and Aquatic Environment, T unis Faculty of Science, University of T unis El Manar, 2092, Tunis, Tunisia
}

Received: Jul 7, 2017, Revised: Jul 30, 2017, Accepted: Aug 13, 2017

\begin{abstract}
In the present study, we aimed to examine the potential protective effect of $C$. aurantinum $L$. peel extract against oxidative damage induced by hexavalent chromiumin the heart of adult rats. Rats were divided into sixgroups. Group I served as contro ls and received standard diet. Group II received via drinking water potassium dichromate $\left(\mathrm{K}_{2} \mathrm{Cr}_{2} \mathrm{O}_{7}\right)$ alone $(700 \mathrm{ppm})$ during 3 weeks. Groups III and IV were pre-treated for 10 days by gavage with the ethanolic extract of $C$. a arantiumpeels at doses of 100 and $300 \mathrm{mg} / \mathrm{kg}$ body weight/day, respectively, and then $\mathrm{K}_{2} \mathrm{Cr}_{2} \mathrm{O}_{7}$ was administrated during 3 weeks. Groups V and VI received by gavage only $C$. a urantiumpeel ethanolic extract at doses of 100 and $300 \mathrm{mg} / \mathrm{kg}$ body weight/day, respectively, during 10 days. $\mathrm{K}_{2} \mathrm{Cr}_{2} \mathrm{O}_{7}$ treatment increased the cardiac levels of malondialdehyde (MDA), protein carbonyls (PCO), advancedoxidation protein products (AOPP), non-protein thiols, glutathione and vitamin $\mathrm{C}$, as well as the activities of catalase, superoxide dismutase and glutathione peroxidase. Cardiac histological alterations, manifested by hemorrhage and cytoplasmic vacuolization, were also observed. Pre-treatment with $C$. aurantium peel extract $(300 \mathrm{mg} / \mathrm{kg})$ attenuated significantly the biochemical and histopathological changes observed following $\mathrm{K}_{2} \mathrm{Cr}_{2} \mathrm{O}_{7}$ exposure in rat's heart. Our findings indicated that $C$. aurantiumpeel extract was able to hamper $\mathrm{K}_{2} \mathrm{Cr}_{2} \mathrm{O}_{7}$-induced myocardial injury, which could be attributed to its antioxidant activity.
\end{abstract}

Keywords: Chromium, rats, heart, oxidative stress, C. aurantiumpeel

Pharm Biomed Res 2017; 3(2): 8-18

\section{Introduction}

Cardiovascular diseases (CVDs) remain one of the most important causes of mortality in the world. Commonly known risk factors, such as hypertension and hypercholesterolemia, can be responsible for only about 50$75 \%$ of all CVDs. Therefore, there is an urgent need to identify new CVD risk factors. A great body of evidence indicates that heavy metal exposure is linked to increased incidence of heart diseases (1).

Hexavalent chromium $(\mathrm{Cr}(\mathrm{VI}))$ is one of the valence states $(+6)$ of the element chromium. It is usually produced by industrial processes and is a source of exposure in the workplace (2). The industrial applications of this metal include painting, electroplating, leather tanning and welding. Workers in $\mathrm{Cr}(\mathrm{VI})$-based industries are highly exposed to this metal which is a major cause of concern. Excessive exposure to $\mathrm{Cr}(\mathrm{VI})$ can be associated with hepatotoxicity (3), nephrotoxicity (4) and carcinogenicity (5) in humans and experimental animals. Moreover, $\mathrm{Cr}(\mathrm{VI})$ has drawn considerable attention as one of the potential cardiotoxic heavy metals. In fact, this element has been demonstrated to accumulate in the heart tissue and to affect the cardiac function both in vivo and in vitro (6). In addition to that, Soudani et al. (7) have shown that $\mathrm{Cr}(\mathrm{VI})$ induces cardiotoxicity in adult rats. The excessive generation of reactive oxygen species (ROS) and the subsequent installation of oxidative stress have been reported to be responsible for the toxic effects of $\mathrm{Cr}(\mathrm{VI})$ in the heart (7). Herbal remedies have been used for the treatment of various illnesses including heart diseases (8). In fact, these herbs constitute a rich source of bioactive phytochemicals such as polyphenols, flavonoids, and other constituents which have been proven to possess beneficial effects in CVDs (9).

Citrus aurantium L., commonly known as bitter orange, is a flowering plant that belongs to the Rutaceae family of the Sapindales order. This species is widely distributed in tropical and subtropical southeast regions of the world. Its flowers and fruits are used for medicinal purposes, mainly as remedies for many disorders of the digestive system, as a cardiac tonic and for anxiety (10). The peel is often used in the formulation of herbal teas due to its flavor profiles, its digestive and carminative effects and for the production of stomachic and laxative products (11). However, citrus fruits 
in general are highly consumed worldwide as fresh produce and juice. The peels, which contain a wide variety of secondary components with substantial antioxidant activity in comparison with other parts of the fruit (12), are most often discarded as waste. In this regard, C. aurantinum peels have been demonstrated to be a rich source of phenolic compounds with significant antioxidant activities (13). The phytochemical study of the fruit peels revealed the presence of citral and limonine, in addition to several citrus bioflavonoids, including hesperidin, neohesperidin, naringin and rutin (14). These compounds have been attributed with a wide range of biological activities including cardioprotective properties. For instance, naringin is believed to cross the blood brain barrier and to have antioxidant and antihypertensive effects (15). Naringinin and hesperdin have been shown to exert anti-atherogenic activity (16). Furthermore, antiplatelet properties have been attributed to hesperidin and neohesperidin (17).

Therefore, the present study firstly was planned to evaluate the beneficial effects of $C$. aurantinum peel ethanolic extract in protecting the myocardium against oxidative damage induced in adult rats by potassium dichromate $\left(\mathrm{K}_{2} \mathrm{Cr}_{2} \mathrm{O}_{7}\right)$.

\section{Materials and methods \\ Chemicals}

$\mathrm{K}_{2} \mathrm{Cr}_{2} \mathrm{O}_{7}$ was purchased from Merck (Darmstadt, Germany). Glutathione (GSH), 5,5'-Dithiobis-2Nitrobenzic acid (DTNB), thiobarbituric acid (TBA), 1,1,3,3-tetrathoxypropane 2,4dinitrophenylhydrazine (DNPH) and nitro blue tetrazolium (NBT) were purchased from Sigma-Aldrich Co. (MO, USA). The other chemicals used in the present study were provided from the standard commercial suppliers Acros Organics and Carlo Erba (USA).

\section{Plant material}

C. aurantium fruits, cultivar laringe, were harvested in the spring from Mars to April from our local garden in the South Suburb of Sfax City (Tunisia). This plant was botanically identified by Dr. Abdelhamid Nabli, Professor Emeritus of Vegetal Biology in Science Faculty of Tunis, Tunisia. A voucher specimen(N-99) was deposited in the herbarium of Pharmacology Laboratory, Faculty of Pharmacy, Monastir, Tunisia.

\section{Preparation of $C$. aurantium peel extract}

C. aurantium peel extract preparation was performed according to the method described by Soudani et al. (18).
Briefly, an amount of $25 \mathrm{mg}$ of $C$. aurantium fruits peel was extracted by refluxing for $5 \mathrm{~h}$ with $500 \mathrm{~mL}$ of ethanol/water $(4 \mathrm{~V} / 1 \mathrm{~V})$. The obtained aqueous ethanol extract was filtered through Whatman No1 filter paper. The filtrate was concentrated to dryness in a rotary evaporator at $50 \pm 1{ }^{\circ} \mathrm{C}$ to give solid residues and then kept at $4{ }^{\circ} \mathrm{C}$ until further use.

Determination of total phenolic content in C. aurantium peel extract

The total phenolic content of $C$. aurantium peel extract was determined using the Folin-Ciocalteu method of JulkunenTitto (19). Results were expressed as mg of caffeic acid equivalents per $\mathrm{g}$ of extract (mg CAE/g extract).

Determination of total flavonoid content in C. aurantium peel extract

Determination of $C$. aurantium extract total flavonoid content was carried out by the aluminium chloride colorimetric method as described by Chang et al. (20). Results were expressed as mg of quercetin equivalents per $\mathrm{g}$ of extract (mg QE/g extract).

Determination of vitamin $C$ content in $C$. aurantium peel extract

Vitamin C content of $C$. aurantium extract was determined by using the titration method involving 2,6 dichloroindophenol (21). Results were expressed as mg/g extract.

\section{DPPH radical scavenging assay}

The capacity of $C$. aurantium extract to scavenge the 2, 2diphenyl-1-picrylhydrazyl (DPPH) free radical was determined according to the method of Bersuder et al. (22). Various concentrations of sample extract $(0.5 \mathrm{~mL})$ were mixed with $0.5 \mathrm{~mL}$ of $99.5 \%$ ethanol and $0.125 \mathrm{~mL}$ of 0.5 mM DPPH solution (dissolved in $99.5 \%$ ethanol). The mixture was shaken and incubated in the dark for $1 \mathrm{~h}$ at room temperature. Then the absorbance was measured at $517 \mathrm{~nm}$. The scavenging activity was calculated based on the percentage of DPPH radical scavenged using the following equation:

DPPH radical - scavenging activity $\%=\frac{A \text { control }- \text { A sample }}{A \text { control }} \times 100$

Vitamin C was used as positive control.

\section{Hydrogen peroxide scavenging activity}

Hydrogen peroxide scavenging activity of $C$. aurantium extract was measured by replacement titration according to 
the method of Zhao et al. (23). $1 \mathrm{~mL}$ of $\mathrm{H}_{2} \mathrm{O}_{2}(0.1 \mathrm{mM})$ and an aliquot of $1 \mathrm{~mL}$ of the peel extract at different concentrations were mixed, followed by 2 drops of $3 \%$ ammonium molybdate, $10 \mathrm{~mL}^{\circ} \mathrm{H}_{2} \mathrm{SO}_{4}(2 \mathrm{M})$ and $7 \mathrm{~mL}$ of $\mathrm{KI}(1.8 \mathrm{M})$. The mixed solution was titrated against $\mathrm{Na}_{2} \mathrm{~S}_{2} \mathrm{O}_{3}(5 \mathrm{mM})$ until dis appearance of yellow color. The relative activity of the test extract to scavenge $\mathrm{H}_{2} \mathrm{O}_{2}$ was expressed as percentage of the titer volume change as follow:

$\%$ inhibition $=((\mathrm{V}$ control- $\mathrm{V}$ sample $) / \mathrm{V}$ control $) \times 100$ Vitamin $\mathrm{C}$ was used as standard.

\section{Reducing power assay}

The reducing power, which reflects the electron donation capacity of bioactive compounds, was monitored by using the method of Oyaizu (24). C. aurantium extract $(0.5 \mathrm{~mL})$ at different concentrations was mixed with $1 \mathrm{~mL}$ of phosphate buffer $(0.2 \mathrm{M}, \mathrm{pH} 6.6)$ and $1 \mathrm{~mL}$ of potassium ferricyanide $(1 \%)$. The mixture was incubated in a water bath at $50^{\circ} \mathrm{C}$ for $20 \mathrm{~min}$. After that, the reaction was stopped by adding $1 \mathrm{~mL}$ of $10 \%$ trichloroacetic acid and the mixture was centrifuged at $20 \times \mathrm{g}$ for $10 \mathrm{~min}$. To $1.5 \mathrm{~mL}$ of the supernatant, $1.5 \mathrm{~mL}$ of deionised water and $0.1 \mathrm{~mL}$ of $0.1 \%$ ferric chloride $\left(\mathrm{FeCl}_{3}\right)$ were added. After allowing the solution to stand for $10 \mathrm{~min}$, the absorbance was measured at $700 \mathrm{~nm}$. Higher absorbance of the reaction mixture indicated stronger reducing power. Vitamin $\mathrm{C}$ w as used as standard.

\section{Animals}

A total of 36 female Wistar rats with an initial mean body weight of $140 \pm 10 \mathrm{~g}$, purchased from the Central Pharmacy (SIPHAT, Tunis, Tunisia), were used in the present work. They were housed under standard laboratory conditions of temperature $\left(22 \pm 2{ }^{\circ} \mathrm{C}\right)$, relative humidity $(40 \%)$ and $12 \mathrm{~h}$ light-dark cycle. Water and commercial standard pellet diet (SICO, Sfax. Tunisia) were provided ad libitum. The experimental study was carried out according to the National Guidelines for Animal Care (25) and approved by the Ethical Committee of Sfax Faculty of Sciences with ethics approval number 1204.

\section{Experimental design and animal grouping}

Rats were randomly divided into six groups of six animals each. Group I served as controls and received standard diet. Group II received via drinking water $\mathrm{K}_{2} \mathrm{Cr}_{2} \mathrm{O}_{7}$ alone (700 ppm) during 3 weeks. Groups III and IV were pre-treated for 10 days by gavage with the ethanolic extract of $C$. aurantium peels at doses of 100 and $300 \mathrm{mg} / \mathrm{kg}$ body weight/day, respectively, and then $\mathrm{K}_{2} \mathrm{Cr}_{2} \mathrm{O}_{7}$ was administrated during 3 weeks. Groups V and VI received by gavage only the ethanolic extract of $C$. aurantium peels at doses of 100 and $300 \mathrm{mg} / \mathrm{kg}$ body weight/day, respectively, during 10 days. The $\mathrm{K}_{2} \mathrm{Cr}_{2} \mathrm{O}_{7}$ dose and the treatment period used in our study were selected on the basis of the previous works of Junaid et al. (26) and Kanojia et al. (27). Regarding C. aurantium peel extract doses, Soudani et al. (18) have previously shown that administration of this plant extract, at 100 and $300 \mathrm{mg} / \mathrm{kg}$, was found to alleviate oxidative stress induced by $\mathrm{Cr}$ (VI) in the lung of adult rats.

At the end of the experimental period, the animals of the different groups were sacrificed by cervical dislocation to avoid stress. Hearts were dissected out and cleaned. Some samples were rinsed and homogenized $(10 \% \mathrm{w} / \mathrm{v})$ by an Ultra-Turrax T25 (IKA, Staufen, Breisgau, Germany) in an appropriate buffer $(\mathrm{pH}=7.4)$ and then centrifuged. The resulting supernatants were used for biochemical assays. Other samples of heart tis sues were immediately removed, cleaned and fixed in $10 \%$ formalin solution for histologic al examination.

\section{Biochemical assays}

\section{Protein estimation in heart}

Protein content in the heart homogenates was determined by following Lowry et al. (28) method, using bovine serum albumin as a standard.

\section{Evaluation of lipid peroxidation in heart}

According to the method of Draper and Hadley (29), the concentration of malondialdehyde (MDA), an endpoint of lipid peroxidation, was measured spectrophotometrically in heart tissues using TEP as a standard. Results were expressed as nmoles/g tissue.

Determination of heart protein carbonyl (PCO) content Heart PCO content was measured using the DNPH method described by Reznick and Packer (30). Results were expressed as nmoles/mg protein.

Determination of heart advanced oxidation protein product (AOPP) levels

The determination of AOPP levels was carried out according to the method of Kayali et al. (31). AOPP concentration was calculated using the extinction coefficient of $261 \mathrm{~cm}^{-1} \mathrm{mM}^{-1}$ and results were expressed as $\mu \mathrm{moles} / \mathrm{mg}$

protein 
Determination of heart antioxidant enzyme activities Catalase (CAT) activity in heart tissue was measured spectorphotometrically at $240 \mathrm{~nm}$ by calculating the rate of $\mathrm{H}_{2} \mathrm{O}_{2}$ degradation (32). CAT activity was expressed as $\mu$ moles $\mathrm{H}_{2} \mathrm{O}_{2}$ consumed $/ \mathrm{min} / \mathrm{mg}$ of protein.

Superoxide dismutase (SOD) activity was estimated according to Beauchamp and Fridovich (33), by monitoring the photochemical reduction of NBT. SOD activity was expressed as units/mg protein, where one unit corresponded to the amount of this enzyme required to cause $50 \%$ inhibition of NBT reduction at $560 \mathrm{~nm}$.

Glutathione peroxidase (GPx) activity was measured according to the protocol of Flohe and Gunzler (34) and results were expressed as nmoles of GSH oxidized $/ \mathrm{min} / \mathrm{mg}$ protein.

\section{Heart GSH content}

The heart GSH content was measured according to the method of Ellman (35) modified by Jollow et al. (36). The principle of this method is based on the development of a yellow color when DTNB is added to compounds containing sulfhydryl groups. Results were expressed as $\mu \mathrm{g} / \mathrm{g}$ tissue.

\section{Heart non-protein thiol (NPSH) content}

Heart NPSH levels were determined according to the method of Ellman (35) and results were expressed as $\mu$ moles/g tissue.

\section{Heart vitamin $C$ content}

Vitamin $\mathrm{C}$ determination was performed as described by Jacques-Silva et al. (37) and results were expressed as $\mu \mathrm{g} / \mathrm{g}$ tissue.

\section{Histopathological studies}

Some heart samples, intended for histological examination, were fixed in $10 \%$ buffered formalin solution, embedded in paraffin blocks and then sectioned at $5 \mu \mathrm{m}$. The obtained sections were deparaffinized, stained with hematoxylineosin (H\&E) and examined for histopathological changes under light microscopy.

\section{Statistical analysis}

All data were presented as means \pm standard deviation (SD). They were analyzed using the statistical package program Stat view 5 Software for Windows (SAS Institute, Berkley, CA). Statistical comparisons between groups were made by means of one-way analysis of variance (ANOVA) followed by Fisher protected least signific ant difference
(PLSD) test as a post hoc test. Student unpaired t test, used for comparison between two groups, was also used when required. Differences were considered significant if $\mathrm{p}<$ 0.05 .

\section{Results}

In vitro study

Antioxidant components in the ethanolic extract of $C$. aurantium

The phytochemical analysis of the antioxidant components of $C$. aurantium extract showed the presence of phenolic compounds, flavonoids and vitamin $\mathrm{C}$ (Table 1).

Table 1 Content of total phenolics, flavonoids and vitamin $\mathrm{C}$ in $C$. aurantium peel extract

\begin{tabular}{lccc}
\hline & Total & Total & Vitamin \\
& phenolics & flavonoids & $\mathrm{C}$ \\
& $\mathrm{mg}$ & $\mathrm{mg} \mathrm{QE} / \mathrm{g}$ & $\mathrm{mg} / \mathrm{g}$ \\
& extract & & \\
\hline$C$. & $92.82 \pm$ & $35.96 \pm$ & $55.55 \pm$ \\
aurantium & 4.42 & 2.68 & 15.71 \\
& & & \\
\hline
\end{tabular}

Values represent the means of three replicates $\pm \mathrm{SD}$.

CAE: Caffeic acid equivalents; QE: Quercetin equivalents.

\section{Antioxidant activity}

Since a single method cannot accurately reflect the antioxidant capacity of plant extracts, different techniques (DPPH radical scavenging activity, $\mathrm{H}_{2} \mathrm{O}_{2}$ scavenging activity, reducing power) were used in our study to evaluate the antioxidant activity of $C$. aurantium. Since it is present in our tested plant extract, vitamin $\mathrm{C}$ was used as a standard for the comparison of the antioxidant power.

\section{$D P P H$ radical scavenging activity}

The scavenging capacity of $C$. aurantium extract on DPPH radical is shown in figure 1 . The results indicated that this extract exhibited an antiradical activity which was enhanced with the increase of the extract concentration. The data obtained showed also that the $\mathrm{IC}_{50}$, the concentration of the tested extract required to decrease $50 \%$ of DPPH initial concentration, was about $0.275 \pm 0.07 \mathrm{mg} / \mathrm{mL}$. However vitamin $\mathrm{C}$, used as a positive control, showed higher antiradical activity than $C$. aurantium extract.

\section{$\mathrm{H}_{2} \mathrm{O}_{2}$ scavenging activity}

The $\mathrm{H}_{2} \mathrm{O}_{2}$ scavenging activity is illustrated in figure 2. $C$. aurantium extract displayed a scavenging capacity against $\mathrm{H}_{2} \mathrm{O}_{2}$ in a concentration dependent manner, but it remained weaker than that of vitamin $\mathrm{C}$ used as a standard reference. 


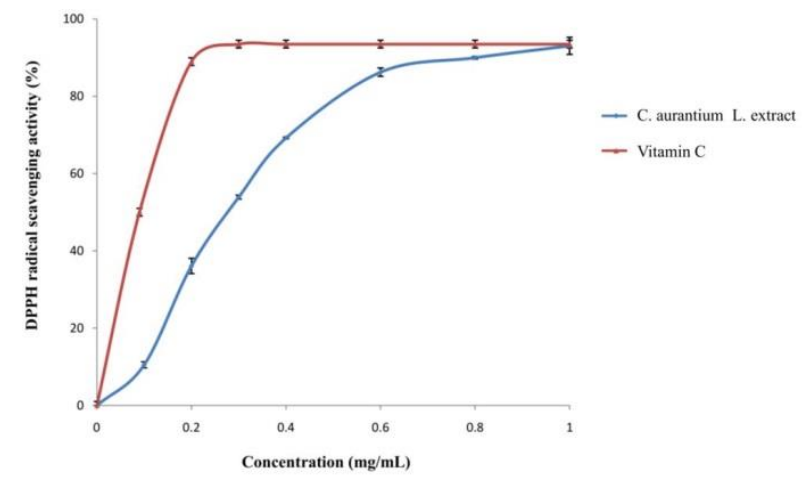

Figure 1 2, 2-diphenyl-1-picry lhy drazyl (DPPH) radical scavenging activity of $C$. aurantium extract in comparison

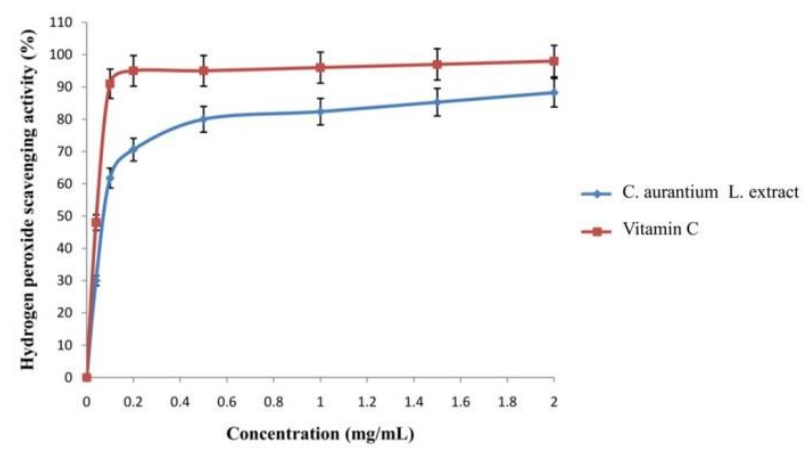

Figure 2 Hydrogen peroxide scavenging activity of $C$. aurantium extract in comparison with vitamin $\mathrm{C}$.

\section{Reducing power}

In our study, $C$. aurantium extract revealed the ability to reduce $\mathrm{Fe}^{3+}$ to $\mathrm{Fe}^{2+}$ in a concentration dependent manner. However, the reducing power of this extract was found to be significantly lower than that of vitamin $\mathrm{C}$ used as a standard (Figure 3).

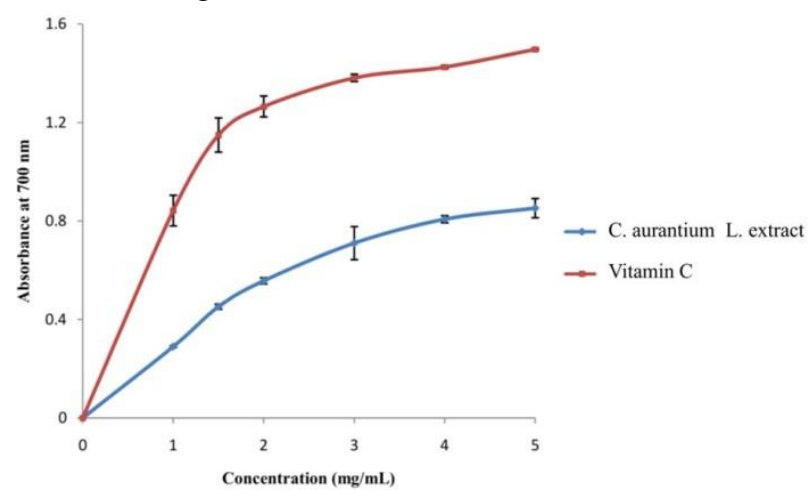

Figure 3 Reducing power of $C$. aurantium extract in comparison with vitamin $\mathrm{C}$.

In vivo study

\section{Lipid peroxidation}

The levels of MDA were significantly increased by $55 \%$ in the heart tissue of $\mathrm{K}_{2} \mathrm{Cr}_{2} \mathrm{O}_{7}$-treated rats, when compared to controls rats. Pre-treatment with $C$. aurantium extract at both doses 100 and $300 \mathrm{mg} / \mathrm{kg}$ bw lowered significantly the MDA cardiac levels by 22 and $31 \%$ respectively, as compared to $\mathrm{K}_{2} \mathrm{Cr}_{2} \mathrm{O}_{7}$-treated rats, without reaching normal values (Table 2).

\section{Protein oxidation}

A signific ant increase in the cardiac levels of PCO $(+129 \%)$ and $\mathrm{AOPP}(+58 \%)$ was observed in $\mathrm{K}_{2} \mathrm{Cr}_{2} \mathrm{O}_{7}$-treated rats, as compared to the controls. Pre-treatment with $C$. aurantium extract at the doses of 100 or $300 \mathrm{mg} / \mathrm{kg}$ bw resulted in a marked decrease in the levels of PCO (-20 and $-46 \%$, respectively) and AOPP (-17 and $-28 \%$, respectively), compared to $\mathrm{K}_{2} \mathrm{Cr}_{2} \mathrm{O}_{7}$-treated rats, without reaching control values (Table 2 ).

Table 2 Malondialdehyde (MDA), protein carbonyls (PCO) and advanced oxidation protein product (AOPP) levels in the heart of control and treated rats with $\mathrm{K}_{2} \mathrm{Cr}_{2} \mathrm{O}_{7}$, C. aurantium $(100 \mathrm{mg} / \mathrm{Kg} \mathrm{bw})$ and $C$. aurantium $(300 \mathrm{mg} / \mathrm{Kg}$ bw) or their combination $\mathrm{K}_{2} \mathrm{Cr}_{2} \mathrm{O}_{7}+C$. aurantium $(100 \mathrm{mg} / \mathrm{Kg}$ bw $)$, $\mathrm{K}_{2} \mathrm{Cr}_{2} \mathrm{O}_{7}+C$. aurantium $(300 \mathrm{mg} / \mathrm{Kg}$ bw $)$.

\begin{tabular}{|c|c|c|c|}
\hline $\begin{array}{l}\text { Parameter and } \\
\text { treatment }\end{array}$ & MDA $^{\mathbf{a}}$ & $\mathbf{P C O}^{\mathbf{b}}$ & $\mathrm{AOPP}^{\mathrm{c}}$ \\
\hline Control & $\begin{array}{l}185.78 \pm \\
5.63\end{array}$ & $\begin{array}{l}78.56 \pm \\
9.80\end{array}$ & $\begin{array}{l}4.48 \pm \\
0.56\end{array}$ \\
\hline $\mathbf{K}_{2} \mathrm{Cr}_{2} \mathbf{O}_{7}$ & $\begin{array}{l}287.78 \pm \\
38.67^{\text {*wak }}\end{array}$ & $\begin{array}{l}179.85 \pm \\
26.69^{* * * *}\end{array}$ & $\begin{array}{l}7.07 \pm \\
0.83^{\text {枮k }}\end{array}$ \\
\hline $\begin{array}{l}\mathrm{K}_{2} \mathrm{Cr}_{2} \mathrm{O}_{7}+C \\
\text { aurantium } \\
(100 \mathrm{mg} / \mathrm{Kg} \text { bw })\end{array}$ & $\begin{array}{l}223.61 \pm \\
26.09^{* * *+}\end{array}$ & $\begin{array}{l}144.70 \pm \\
18.33^{* * *_{+}}\end{array}$ & $\begin{array}{l}5.90 \pm \\
0.96^{* *_{+}}\end{array}$ \\
\hline $\begin{array}{l}\mathrm{K}_{2} \mathrm{Cr}_{2} \mathrm{O}_{7}+C . \\
\text { aurantium } \\
(300 \mathrm{mg} / \mathrm{Kg} \text { bw })\end{array}$ & $\begin{array}{l}198.71 \pm \\
10.05^{*+++}\end{array}$ & $\begin{array}{l}97.93 \pm \\
11.35^{*++1+}\end{array}$ & $\begin{array}{l}5.10 \pm \\
0.55^{*++1}\end{array}$ \\
\hline $\begin{array}{l}\text { C. aurantium } \\
(100 \mathrm{mg} / \mathrm{Kg} \text { bw) }\end{array}$ & $\begin{array}{l}179.96 \pm \\
7.29\end{array}$ & $\begin{array}{l}81.65 \pm \\
8.92\end{array}$ & $\begin{array}{l}4.20 \pm \\
0.37\end{array}$ \\
\hline $\begin{array}{l}\text { C. aurantium } \\
(300 \mathrm{mg} / \mathrm{Kg} \text { bw) }\end{array}$ & $\begin{array}{l}175.81 \pm \\
15.10\end{array}$ & $\begin{array}{l}88.75 \pm \\
18.80\end{array}$ & $\begin{array}{l}4.02 \pm \\
0.83\end{array}$ \\
\hline \multicolumn{4}{|c|}{ 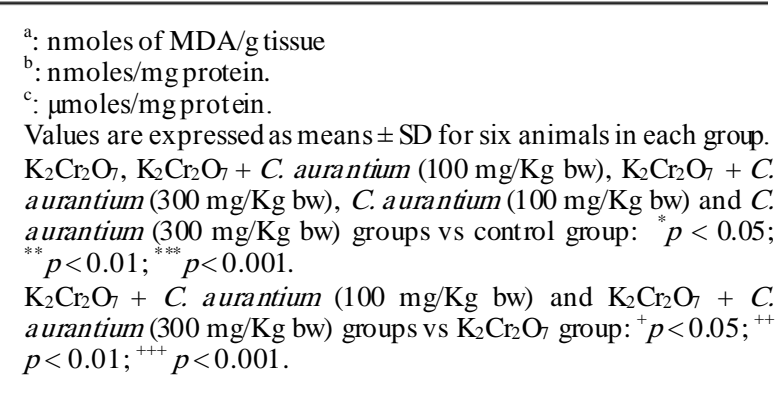 } \\
\hline
\end{tabular}

\section{Enzymatic antioxidant status}

Rats exposure to $\mathrm{K}_{2} \mathrm{Cr}_{2} \mathrm{O}_{7}$ resulted in signific antly enhanced activities of SOD, CAT and GPx $(+24,+133$ and $+65 \%$, 
respectively) in the heart tis sue, as compared to the controls (Table 3). Pre-treatment with $C$. aurantium extract at the dose of $100 \mathrm{mg} / \mathrm{kg}$ bw led to a no significant decrease of CAT $(-14 \%)$, SOD (-6\%) and GPx (-4\%) cardiac activities, as compared to $\mathrm{K}_{2} \mathrm{Cr}_{2} \mathrm{O}_{7}$-treated rats. Pre-treatment with this plant extract at $300 \mathrm{mg} / \mathrm{kg}$ body weight was more effective in decreasing CAT $(-44 \%)$ and GPx $(-30 \%)$ activities, without reaching the control values, and reverted back SOD activity $(-17 \%)$ to near normal value.

\section{Non-enzymatic antioxidant status}

Following $\mathrm{K}_{2} \mathrm{Cr}_{2} \mathrm{O}_{7}$ exposure, heart levels of GSH, NPSH and vitamin $\mathrm{C}$ were enhanced respectively by 30, 94 and $37 \%$, when compared to the controls (Table 4). Pretreatment with $C$. aurantium extract at the dose of 100 $\mathrm{mg} / \mathrm{kg}$ produced a

Table 3 Catalase (CAT), superoxide dismutase (SOD) and glutathione peroxidase (GPx) activities in the heart of control and treated rats with $\mathrm{K}_{2} \mathrm{Cr}_{2} \mathrm{O}_{7}, C$. aurantium (100 $\mathrm{mg} / \mathrm{Kg} \mathrm{bw})$ and $C$. aurantium $(300 \mathrm{mg} / \mathrm{Kg}$ bw) or their combination $\mathrm{K}_{2} \mathrm{Cr}_{2} \mathrm{O}_{7}+C$. aurantium $(100 \mathrm{mg} / \mathrm{Kg} \mathrm{bw})$, $\mathrm{K}_{2} \mathrm{Cr}_{2} \mathrm{O}_{7}+$ C. aurantium $(300 \mathrm{mg} / \mathrm{Kg}$ bw $)$.

\begin{tabular}{|c|c|c|c|}
\hline $\begin{array}{l}\text { Parameter and } \\
\text { treatment }\end{array}$ & CAT $^{\mathbf{a}}$ & $\mathrm{SOD}^{6}$ & GPx $^{c}$ \\
\hline Control & $\begin{array}{l}56.57 \pm \\
6.03\end{array}$ & $\begin{array}{l}740.87 \pm \\
90.34\end{array}$ & $\begin{array}{l}20.99 \pm \\
1.29\end{array}$ \\
\hline $\mathrm{K}_{2} \mathrm{Cr}_{2} \mathrm{O}_{7}$ & $\begin{array}{l}131.75 \pm \\
27.47^{* * 1 \%}\end{array}$ & $\begin{array}{l}916.66 \pm \\
65.69^{* *}\end{array}$ & 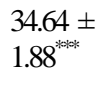 \\
\hline $\begin{array}{l}\mathrm{K}_{2} \mathrm{Cr}_{2} \mathrm{O}_{7}+C . \\
\operatorname{aurantium}(100 \\
\mathrm{mg} / \mathrm{Kg} \mathrm{bw})\end{array}$ & $\begin{array}{l}112.73 \pm \\
11.23^{* * 6 \%}\end{array}$ & $\begin{array}{l}863.92 \pm \\
62.71^{* *}\end{array}$ & $\begin{array}{l}33.31 \pm \\
1.77^{* * \cdots * k}\end{array}$ \\
\hline $\begin{array}{l}\mathrm{K}_{2} \mathrm{Cr}_{2} \mathrm{O}_{7}+C . \\
\operatorname{aurantium}(300 \\
\mathrm{mg} / \mathrm{Kg} \mathrm{bw})\end{array}$ & $\begin{array}{l}74.05 \pm \\
8.64^{* *+1+}\end{array}$ & $\begin{array}{l}763.38 \pm \\
58.01^{++}\end{array}$ & $\begin{array}{l}24.32 \pm \\
1.99^{* * * *+++}\end{array}$ \\
\hline $\begin{array}{l}\text { C. aurantium } \\
(100 \mathrm{mg} / \mathrm{Kg} \\
\text { bw) }\end{array}$ & $\begin{array}{l}54.01 \pm \\
14.87\end{array}$ & $\begin{array}{l}689.25 \pm \\
90.92\end{array}$ & $\begin{array}{l}23.08 \pm \\
2.58\end{array}$ \\
\hline $\begin{array}{l}\text { C. aurantium } \\
(300 \mathrm{mg} / \mathrm{Kg} \\
\text { bw) }\end{array}$ & $\begin{array}{l}55.28 \pm \\
13.52\end{array}$ & $\begin{array}{l}730.44 \pm \\
82.68\end{array}$ & $\begin{array}{l}24.88 \pm \\
5.13\end{array}$ \\
\hline
\end{tabular}

a: $\mu$ moles $\mathrm{H}_{2} \mathrm{O}_{2}$ degraded $/ \mathrm{min} / \mathrm{mg}$ protein.

b: units/mg protein.

c: nmoles of $\mathrm{GSH} / \mathrm{min} / \mathrm{mg}$ protein

Values are expressed as means \pm SD for six animals in each group.

$\mathrm{K}_{2} \mathrm{Cr}_{2} \mathrm{O}_{7}, \mathrm{~K}_{2} \mathrm{Cr}_{2} \mathrm{O}_{7}+C$. aurantium $\left(100 \mathrm{mg} / \mathrm{Kg}\right.$ bw), $\mathrm{K}_{2} \mathrm{Cr}_{2} \mathrm{O}_{7}+$ C. aurantium $(300 \mathrm{mg} / \mathrm{Kg} \mathrm{bw}), C$. aurantium $(100 \mathrm{mg} / \mathrm{Kg} \mathrm{bw})$ and $C$. aurantium $\left(300 \mathrm{mg} / \mathrm{Kg}\right.$ bw) groups vs control group: ${ }^{* *} p$ $<0.01 ;{ }^{* * *} p<0.001$.

$\mathrm{K}_{2} \mathrm{Cr}_{2} \mathrm{O}_{7}+C$. a urantium $\left(100 \mathrm{mg} / \mathrm{Kg}\right.$ bw) and $\mathrm{K}_{2} \mathrm{Cr}_{2} \mathrm{O}_{7}+C$. aurantium $\left(300 \mathrm{mg} / \mathrm{Kg}\right.$ bw) groups vs $\mathrm{K}_{2} \mathrm{Cr}_{2} \mathrm{O}_{7}$ group: ${ }^{++} p<$ $0.01 ;{ }^{+++} p<0.001$ significant decrease in NPSH level by $11 \%$, as compared to $\mathrm{K}_{2} \mathrm{Cr}_{2} \mathrm{O}_{7}$-treated rats, without reaching normal values, while it failed to reverse $\mathrm{GSH}$ and vitamin $\mathrm{C}$ levels. Compared to $\mathrm{K}_{2} \mathrm{Cr}_{2} \mathrm{O}_{7}$-treated rats, pre-treatment with this extract at the dose of $300 \mathrm{mg} / \mathrm{kg}$ reduced signific antly GSH, NPSH and vitamin C levels by 14,37 and $18 \%$ respectively, without reaching the control values (Table 4).

\section{Histological findings}

Light microscopic examination of heart sections from control rats revealed normal histological structures (Figure 4(A)). Nevertheless, heart sections of $\mathrm{K}_{2} \mathrm{Cr}_{2} \mathrm{O}_{7}$-treated rats showed structural changes in this tissue characterized by hemorrhage and cytoplasmic vacuolization of cardiac muscle cells (Figure 4(B)). These histological alterations were markedly reduced by pre-treatment with $C$. aurantium at the tw o tested doses (Figure 4(C1, C2)). Normal cardiac architecture was observed

Table 4 Glutathione (GSH), non-protein thiols (NPSH), and vitamin $\mathrm{C}$ levels in the heart of control and treated rats with $\mathrm{K}_{2} \mathrm{Cr}_{2} \mathrm{O}_{7}, C$. aurantium $(100 \mathrm{mg} / \mathrm{Kg}$ bw $)$ and $C$. aurantium $(300 \mathrm{mg} / \mathrm{Kg}$ bw) or their combination $\mathrm{K}_{2} \mathrm{Cr}_{2} \mathrm{O}_{7}+C$. aurantium $(100 \mathrm{mg} / \mathrm{Kg} \mathrm{bw}), \mathrm{K}_{2} \mathrm{Cr}_{2} \mathrm{O}_{7}+C$. aurantium $(300 \mathrm{mg} / \mathrm{Kg}$ bw).

\begin{tabular}{|c|c|c|c|}
\hline $\begin{array}{l}\text { Parameter and } \\
\text { treatment }\end{array}$ & GSH $^{\mathrm{a}}$ & NPSH $^{b}$ & Vitamin $\mathbf{C}^{\mathrm{c}}$ \\
\hline Control & $\begin{array}{l}147.90 \pm \\
14.09\end{array}$ & $\begin{array}{l}6.21 \pm \\
0.46\end{array}$ & $\begin{array}{l}96.34 \pm \\
8.24\end{array}$ \\
\hline $\mathbf{K}_{2} \mathrm{Cr}_{2} \mathrm{O}_{7}$ & $\begin{array}{l}192.41 \pm \\
13.22^{\text {*ioke }}\end{array}$ & $\begin{array}{l}12.07 \pm \\
0.51^{\text {seope }}\end{array}$ & $\begin{array}{l}131.73 \pm \\
8.59^{\text {voloke }}\end{array}$ \\
\hline $\begin{array}{l}\mathrm{K}_{2} \mathrm{Cr}_{2} \mathrm{O}_{7}+C . \\
\text { aurantium }(100 \\
\text { mg/Kg bw) }\end{array}$ & $\begin{array}{l}191.31 \pm \\
10.61^{\text {*eok }}\end{array}$ & $\begin{array}{l}10.71 \pm \\
0.62^{\operatorname{logk}_{+}+}\end{array}$ & $\begin{array}{l}124.20 \pm \\
11.61^{\text {*owk }}\end{array}$ \\
\hline $\begin{array}{l}\mathrm{K}_{2} \mathrm{Cr}_{2} \mathrm{O}_{7}+C . \\
\text { aurantium } \\
(300 \mathrm{mg} / \mathrm{Kg} \text { bw) }\end{array}$ & $\begin{array}{l}164.92 \pm \\
9.02^{*+1+}\end{array}$ & $\begin{array}{l}7.62 \pm \\
0.71^{* *+1+}\end{array}$ & $\begin{array}{l}107.53 \pm \\
5.73^{*+1+}\end{array}$ \\
\hline $\begin{array}{l}\text { C. aurantium } \\
(100 \mathrm{mg} / \mathrm{Kg} \text { bw })\end{array}$ & $\begin{array}{l}145.15 \pm \\
5.36\end{array}$ & $\begin{array}{l}6.63 \pm \\
0.41\end{array}$ & $\begin{array}{l}99.08 \pm \\
8.34\end{array}$ \\
\hline $\begin{array}{l}\text { C. aurantium } \\
(300 \mathrm{mg} / \mathrm{Kg} \text { bw })\end{array}$ & $\begin{array}{l}144.91 \pm \\
12.58\end{array}$ & $\begin{array}{l}6.22 \pm \\
0.55\end{array}$ & $\begin{array}{l}104.33 \pm \\
10.69\end{array}$ \\
\hline
\end{tabular}

\footnotetext{
a $\mu \mathrm{g} / \mathrm{g}$ tissue

$\mathrm{b}:$ nmoles/g tissue

c. $\mu \mathrm{g} / \mathrm{g}$ tissue

Values are expressed as means \pm SD for six animals in each group.

$\mathrm{K}_{2} \mathrm{Cr}_{2} \mathrm{O}_{7}, \mathrm{~K}_{2} \mathrm{Cr}_{2} \mathrm{O}_{7}+$ C. aurantium $(100 \mathrm{mg} / \mathrm{Kg} \mathrm{bw}), \mathrm{K}_{2} \mathrm{Cr}_{2} \mathrm{O}_{7}+$ C. aurantium $(300 \mathrm{mg} / \mathrm{Kg} \mathrm{bw}), C$. aurantium $(100 \mathrm{mg} / \mathrm{Kg}$ bw) and $C$. aurantium $\left(300 \mathrm{mg} / \mathrm{Kg}\right.$ bw) groups vs control group: ${ }^{*} p<$ $0.05 ;{ }^{* *} p<0.01 ;{ }^{* * *} p<0.001$.

$\mathrm{K}_{2} \mathrm{Cr}_{2} \mathrm{O}_{7}+C$. aurantium $\left(100 \mathrm{mg} / \mathrm{Kg}\right.$ bw) and $\mathrm{K}_{2} \mathrm{Cr}_{2} \mathrm{O}_{7}+C$. aurantium $\left(300 \mathrm{mg} / \mathrm{Kg}\right.$ bw) groups vs $\mathrm{K}_{2} \mathrm{Cr}_{2} \mathrm{O}_{7}$ group: ${ }^{++} p<$ $0.01 ;{ }^{+++} p<0.001$.
} 
in heart sections of rats treated only with $C$. aurantium at both doses (Figure 4(D1, D2)).

\section{Discussion}

The present study provides the first evidence on the preventive effect of the ethanolic extract prepared from $C$. aurantium peels against myocardial oxidative injury induced in the heart of $\mathrm{Cr}(\mathrm{VI})$ exposed adult rats.

$\mathrm{Cr}(\mathrm{VI})$ is one of the most ubiquitous and toxic heavy metals. In recent years, there has been an increasing ecological and public health concern associated with environmental contamination by this metal. In fact, $\mathrm{Cr}$ (VI) has been reported to cause a number of clinical complications including cardiotoxic effects. Oxidative stress has been reported among the main contributing factors to the cardiotoxicity induced by this metallic element.

Lipid peroxidation is one of the major manifestations of $\mathrm{Cr}(\mathrm{VI})$ induced cardiac oxidative damage (7). This process is activated by the highly reactive hydroxyl radical through extracting an allylic hydrogen from polyunsaturated
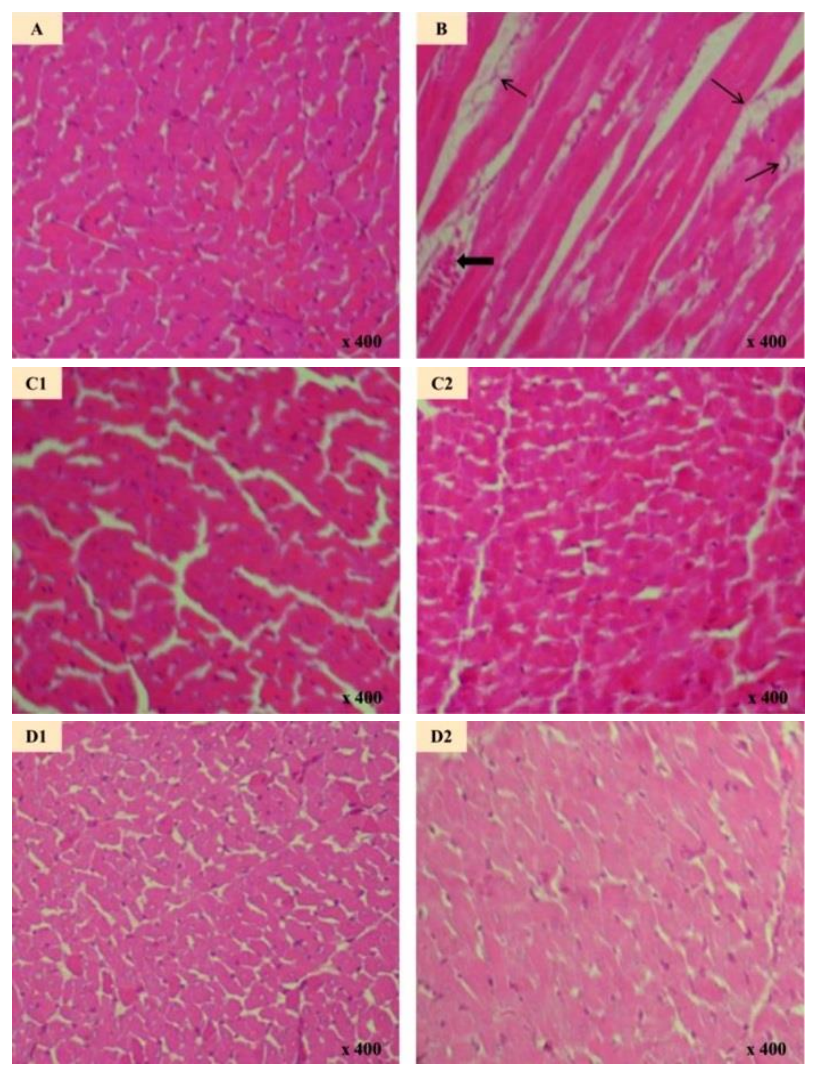

Figure 4 Heart histological sections of control (A) and treated rats with $\mathrm{K}_{2} \mathrm{Cr}_{2} \mathrm{O}_{7}$ (B), $\mathrm{K}_{2} \mathrm{Cr}_{2} \mathrm{O}_{7}+\mathrm{C}$. aurantium at $100 \mathrm{mg} / \mathrm{kg}$ bw (C1), $\mathrm{K}_{2} \mathrm{Cr}_{2} \mathrm{O}_{7}+\mathrm{C}$. aurantium at $300 \mathrm{mg} / \mathrm{kg}$ bw (C2), C. aurantium at $100 \mathrm{mg} / \mathrm{kg}$ bw (D1) or C. aurantium at $300 \mathrm{mg} / \mathrm{kg}$ bw (D2). Optic microscopy: Hematoxylin \& Eosin (x400).

The arrows indicate :

Hemonhage 7 Vacuolization fatty acids of cell membranes. In the present study, increased levels of MDA, the end product of lipid peroxidation, were observed in the heart tis sue of $\mathrm{K}_{2} \mathrm{Cr}_{2} \mathrm{O}$ treated rats, confirming the earlier findings of Soudani et al. (7). This result reflected oxidative damage of the myocardial membrane lipids due to an increased generation of hydroxyl radicals associated with chromium reduction. In fact, $\mathrm{Cr}(\mathrm{VI})$ can easily pas s through cell membranes via non-specific anion transporters. Inside the cell, $\mathrm{Cr}(\mathrm{VI})$ is metabolically reduced to reactive intermediates such as $\mathrm{CrV}$, CrIV and CrIII. During this process, molecular oxygen is reduced to superoxide anion, which is further converted, by dismutation, to hydrogen peroxide $\left(\mathrm{H}_{2} \mathrm{O}_{2}\right)$. The resultant intermediates react with $\mathrm{H}_{2} \mathrm{O}_{2}$ to generate, via Haber-Weiss- or Fenton-like reaction, hydroxyl radicals (38), causing diverse cytotoxic effects.

However, pre-treatment with the two tested doses of the ethanolic extract of $C$. aurantium resulted in a significantly low er degree of lipid peroxidation in the heart of adult rats. These improvements were in a dose related manner. This may be attributed to the inhibitory effect of this extract on lipid peroxidation, resulting in the protection of integrity and functioning of tissues and cells. The anti-lipid peroxidative effect of $C$. aurantium extract could be ascribed to its ROS scavenging activity. In fact, in our present study, the in vitro evaluation of the antioxidant capacity of $C$. aurantium extract showed that this extract is endowed with a $\mathrm{H}_{2} \mathrm{O}_{2}$ scavenging activity. Moreover, this extract was found to display an antiradical activity against DPPH radicals reflecting its potent proton-donating ability. C. aurantium extract exerted also a reducing power which could be due to the presence of reductones, being involved in breaking the free radical chain reaction. So, it can be suggested that $C$. aurantium extract decreased the levels of pro-oxidant agents like $\mathrm{H}_{2} \mathrm{O}_{2}$ and/or neutralized free radicals produced during the metabolic reduction of $\mathrm{Cr}(\mathrm{VI})$ in the heart of adult rats which protected lipid membranes from oxidative insult.

Irreversible protein modific ation such as the generation of carbonyls is another consequence of oxidative stress. The excessive ROS generation can trigger protein autooxidation with consequent formation of PCO and AOPP (39), valuable markers of oxidant-mediated protein damage. Protein oxidative modification alters the biological properties of these biomolecules leading consequently to their fragmentation, increased aggregation and enzyme dysfunction (39). Earlier studies showed that chromium exposure induces protein oxidation in several organs of experimental rodents such as uterus and ovaries of female 
rats (40), mouse liver (41) and rat lung (18), while no information is available regarding the heart tissue. Results from our study showed for the first time the increased levels of PCO and AOPP in the heart of $\mathrm{K}_{2} \mathrm{Cr}_{2} \mathrm{O}$-treated rats. These findings postulate protein oxidation as a possible mechanism by which this heavy metal mediates its cardiotoxic effects. Increasing evidence suggests that irreversible oxidative modifications of proteins are important in the pathophysiology of CVDs (42).

Notably, pre-treatment with $C$. aurantium extract at the high and low doses reduced the damage to proteins as evidenced by the decreased cardiac levels of PCO and AOPP. How ever, better results were obtained using the high dose. Attenuation of protein oxidation may be due to the ROS scavenging capacity and the reducing ability of this extract.

The myocardium has different antioxidative mechanisms to alleviate oxidative challenge and repair the damaged macromolecules. The primary defense is offered by enzymatic antioxidants such as SOD, CAT and GPx, which have been shown to scavenge ROS. Non-enzymatic antioxidants constitute a second line of cellular defense against free radicals. Among them, GSH is considered to be the most important antioxidant. This sulfhydryl containing tripeptide is the most abundant non-protein thiol which functions as an antioxidant through donating its reducing equivalents to unstable species like free radicals. GSH is also directly involved in recycling vitamin $\mathrm{C}$, a water soluble antioxidant compound well recognized for its powerful inhibitor effect on lipid peroxidation in biologic al systems. In agreement with the previous findings of Soudani et al. (7), our data demonstrated a marked increase in myocardium SOD, CAT and GPx activities in $\mathrm{K}_{2} \mathrm{Cr}_{2} \mathrm{O}$ treated rats. A similar pattern was observed regarding the cardiac levels of NPSH, GSH and vitamin C. These results reflect probably an adaptive response towards the increased ROS generation following $\mathrm{Cr}$ (VI) exposure.

Interestingly, a signific ant decrease in the cardiac activities of CAT, SOD and GPx, as well as the levels of GSH, NPSH and vitamin $\mathrm{C}$ was observed in rats pre-treated with C. aurantium extract at the dose of $300 \mathrm{mg} / \mathrm{kg}$ bw, as compared to chromium exposed rats. Using the dose of 100 $\mathrm{mg} / \mathrm{kg} \mathrm{bw}$ was found to reduce changes in NPSH level, while no significant improvement was observed regarding CAT, SOD, GPx, GSH and vitamin C. A possible explanation for the observed decrement in the antioxidant status of rats pre-treated with $C$. aurantium as compared to $\mathrm{K}_{2} \mathrm{Cr}_{2} \mathrm{O}$-treated rats, is that this extract through its antioxidant capacity, helped the endogenous enzymatic and non-enzymatic antioxidants in the removal of ROS generated by $\mathrm{Cr}(\mathrm{VI})$ which led to the decrease of their levels.

Our biochemical data are in close agreement with the histopathological findings of the cardiac tissue. Indeed, $\mathrm{Cr}(\mathrm{VI})$ exposure induced alterations of the normal heart histoarchitecture, manifested by hemorrhage and cytoplasmic vacuolization of cardiac muscle cells, a step known to precede the necrosis process. These morphological pathologies could result from the increased generation of ROS following Cr(VI) exposure. Similar histopathological observations were reported by Soudani $e t$ al. (7). Pre-administration of $C$. aurantium extract at both doses to $\mathrm{K}_{2} \mathrm{Cr}_{2} \mathrm{O}$-treated rats showed a protective effect with less disruption of the cardiac tissue, confirming its effic acy against the cardiotoxicity of this metal.

The antioxidant and cardioprotective beneficial effect of $C$. aurantium peel extract may be attributed to its bioactive phytochemical constituents. In fact, we have shown in the present study that this extract contains considerable amounts of vitamin $\mathrm{C}$, phenolic compounds and flavonoids. The presence of condensed tannins has been also reported previously by Soudani et al. (18).

The usefulness of vitamin $\mathrm{C}$ as a cardioprotective agent has been well documented (43). It is also worth mentioning that in our in vitro study, vitamin $\mathrm{C}$ showed a more efficient antioxidant activity than the tested plant extract. How ever, in our in vivo study, C. aurantium peel extract was used for the treatment of cardiotoxicity associated with $\mathrm{Cr}(\mathrm{VI})$ exposure. Indeed, our purpose was to valorize the peels of this plant, which are considered as by-products and often discarded as waste, in order to evaluate their potential use as a dietary source of flavonoids, that could be used in protecting persons exposed to $\mathrm{Cr}(\mathrm{VI})$ in the workplace. Phenolic compounds, as well, can act as antioxidants through several mechanisms including radical scavenging (44), singlet oxygen quenching (45) and metal chelation (46). Growing evidence from epidemiological studies strongly support that phenolic compounds contribute to the prevention of CVDs $(47,48)$. The identific ation of the phenolic compounds present in the ethanolic extract of $C$. aurantium peel has been previously performed by Soudani et al. (18) using HPLC/MS. These authors have shown the richness of this extract in naringin, naringenin, quercetin, poncirin, isosinensetin and tetramethyl-o-isoscutellarein. Naringin, naringenin and quercetin are the strong scavengers of free radic als and prevent lipid peroxidation (49, 50). The ameliorative effects of these flavonoids against cardiac toxicity in rats have been reported in several 
reports. In fact, pre-treatment with naringin or quercetin was shown to be effective in preventing cardiotoxicity associated with isoproterenol exposure in rats $(51,52)$. Moreover, the prior administration of naringenin ahead of doxorubic in challenge was found to attenuate cardiac oxidative damage induced by this antibiotic in rats (53). In addition to that, cardioprotective properties such as antihypertensive (15) and antiatherogenic (16) activities have been attributed to naringin and naringinin respectively. Quercetin has been also demonstrated to exert blood pressure lowering effects (54). In our present work, we showed that $\mathrm{Cr}(\mathrm{VI})$ treatment induced oxidative stress in the heart tissue. Considerable evidence indicates that the oxidative stress process plays a pivotal role in the progression of CVDs such as atherosclerosis (55), hypertension (56) and heart failure (57). Based on these data, $C$. aurantium peel extract could be suggested in the treatment of pathological conditions related to heart diseases. Future investigations are required to examine these suggestions.

Hence, the mechanisms of the protective effect of C. aurantium peel extract against $\mathrm{Cr}(\mathrm{VI})$ myocardial injury could be explained by the ROS scavenging properties of its bioactive compounds. Moreover, we cannot exclude the possibility of this extract exerting a metal chelating effect on $\mathrm{Cr}(\mathrm{VI})$, probably due to the presence of tannins, which are widely used as chelating agents. In accordance with our findings, the cardioprotective effect of other Citrus species, namely Citrus hystix (peel ethanolic extract) and Citrus medica (fruit ethanolic extract), has been also proven by other researchers $(58,59)$.

In addition to that, the hepatoprotective effect of $C$. aurantium peel extract was recently evaluated in three different models of hepatic damage. Choi et al. (60) have reported that this extract shows antioxidant activity and ameliorates ethanol-induced liver injury through modulating adenosine monophosphate activated protein kinase and nuclear factor erythroid-2-related factor 2 in a bindge drinking mouse model. Likewise, Kim et al. (61) and Lim et al. (62) have demonstrated that $C$. aurantium peel extract regulates efficiently, with its antioxidant, antiinflammatory and antiapoptotic activities, carbon tetrachloride and bile duct ligation-induced hepatotoxicity in mice. Taken together, these data underline the therapeutic values of $C$. aurantium peel extract.

\section{Conclusion}

In summary, the biochemic al and histopathological data obtained from the present study indicated that $C$. aurantium peel extract offered, in a dose dependent manner, a protection to the myocardium of adult rats against $\mathrm{K}_{2} \mathrm{Cr}_{2} \mathrm{O}_{7}$ induced cardiac oxidative damage. The protective effect of C. aurantium could be attributed to the combined antioxidant activities of its different bioactive phytochemical constituents. Therefore, $C$. aurantium peel may be valorized for the development of beneficial nutraceuticals to combat cardiotoxicity associated with Cr(VI) exposure.

\section{Acknowledgment}

This work was supported by the Ministry of Higher Education and Scientific Research, (DGRST grants, UR/13 ES-35), Tunisia.

\section{Conflict of interest}

The authors declare that there is no conflict of interest.

\section{Authors' contribution}

All authors contributed in the studies performed and in the preparation of the manuscript.

\section{References}

1. Alissa EM, Ferns GA. Heavy metal poisoning and cardiovascular disease. J Toxicol 2011;2011 (Article ID 870125).

2. CostaM, Klein CB. Toxicity and carcinogenicity of chromium compounds in humans. Crit Rev Toxicol 2006;36:155-63.

3. Das J, Sarkar A, Sil PC. Hexavalent chromium induces apoptosis in human liver (HepG2) cells via redox imbalance. Toxicol Rep 2015;2:600-8.

4. Saber TM, Farag MR, Cooper RG. Ameliorative effect of extra virgin olive oil on hexavalent chromium-induced nephrotoxicity and genotoxicity in rats. Revue Méd Vét 2015;166:11-9.

5. Stern AH. A quantitative assessment of the carcinogenicity of hexavalent chromium by the oral route and its relevance to human exposure. Environ Res 2010;110:798-807.

6. Chang HR, Tsao DA, Tseng WC. Hexavalent chromium inhibited the expression of RKIP of heart in vivo and in vitro. Toxicol in Vitro 2011;25:1-6.

7. Soudani N, Troudi A, BouazizH, BenAmara I, Boudawara T, Zeghal N. Cardioprotective effects of selenium on chromium (VI)-induced toxicity in female rats. Ecotox Environ Safe 2011;74:513-20.

8. Xiong X, Yang X, Liu Y, Zhang Y, Wang P, Wang J. Chinese herbal formulas for treating hypertension in traditional Chinese medicine: perspective of modern science. Hypertens Res 2013;36:570-9.

9. Kishimoto Y, Tani M, Kondo K. Pleiotropic preventive effects of dietary polyphenols in cardiovascular diseases. Eur J Clin Nutr 2013; 67:532-5.

10. Rhind JP. Fragrance and Wellbeing: Plant Aromatics and Their Influence on the Psche. 1st ed. Singing Dragon Publications: Philadelpia; 2014. p. 331-8.

11. Leung AY, Foster S. Enclyclopedia of Natural Ingredients Used in Foods, Drugs, and Cosmetics. New York: John Wiley; 1996.

12. Manthey JA, Grohmann K. Phenols in citrus peel byproducts. Concentrations of hydroxycinnamates and polymethoxylated flavones in citrus peel molasses. J Agric Food Chem 2001;49:3268-73.

13. Jabri karoui I, Marzouk B. Characterization of bioactive compounds in Tunisian bitter orange (Citrus aurantium L.) peel and juice and 
determination of their antioxidant activities. BioMed Res Int 2013;2013 (Article ID 345415).

14. Tripathy PP, George OD. Evaluation of antimicrobial activity of ZITRITIDE, a natural and organic antimicrobial fogging solution with special referencefor infection prevention and control in hospital environments and all other clean room facilities. Int J Curr Microbiol App Sci 2017;6:1822-37.

15. Chanet A, Milenkovic D, Manach C, Mazur A, Morand C. Citrus flav anones: what is their role in cardiovascular protection? J Agric Food Chem 2012;60: 8809-22.

16. Liu L, Shan S, Zhang K, Ning Z, Lu X, Cheng Y. Naringenin and hesperetin, two flavonoids derived from Citrus aurantium up-regulate transcription of adiponectin. Phyther Res 2008;22:1400-3.

17. Majumdar S, Srirangam R. Solubility, stability, physicochemical characteristics and in vitro ocular tissue permeability of hesperidin: a natural bioflavonoid. Pharm Res 2009;26:1217-25.

18. Soudani N, Rafrafi M, Ben Amara I, Hakim A, Troudi A, Zeghal KM, et al. Oxidative stress-related lung dysfunction by chromium(VI): alleviation by Citrus aurantium L. J Physiol Biochem 2013;69:239-53 .

19. Julkunen-Titto R. Phenolics constituents in the leaves of northern willows: methods for the analysis of certain phenolics. J Agric Food Chem 1985; 33:213-7.

20. Chang C, Yang M, Wen H, Chern J. Estimation of total flavonoid content in propolice by two complementary colorimetric methods. J Food Drug Anal 2002; 10:178-82.

21. AOAC. Official Method 967.21 . Ascorbic acid in vitamin preparations and juices, 2, 6-Dichlorophenol Titrimetric Method. AOAC Int 2006;7:50-81.

22. Bersuder P, Hole M, Smith G. Antioxidants from a heated histidine glucose model system I: investigation of the antioxidant role of histidine and isolation of antioxidants by high performance liquid chromatography. J Am Oil Chem Soc 1998;75:181-7.

23. Zhao GR, Xiang ZJ, Ye TX, Yuan YJ, Guo ZX. Antioxidant activities of Salvia miltiorhiza and Panax notoginseng. Food Chem 2006;99:767-74

24. Oyaizu M. Studies on products of browning reaction prepared from glucoseamine. Jpn J Nutr 1986;44 :307-14.

25. Council of European Communities, Council instructions about the protection of living animals used in scientific investigations. OJEC (JO 86/609/CEE) 1986;358:1-18

26. Junaid M, Murthy RC, Saxena DK. Embryo and fetotoxicity of chromium in pregestationally exposed mice. Bull Environ Contam Toxicol 1996;57:327-34

27. KanojiaRK, Junaid M, Murthy RC. Embryo and fetotoxicity of hex avalent chromium: a long-term study. Toxicol Lett 1998;95:165-72

28. Lowry OH, Rosebrugh NJ, Farr AL, Randall RJ. Protein measuremernt with the Folin phenol reagent. J Biol Chem 1951;193:265-75.

29. Draper HH, Hadley M. Malondialdehyde determination asindex of lipid peroxidation. Methods Enzymol 1990;186:421-31.

30. Reznick AZ, Packer L. Oxidative damage to proteins: spectrophotometric method for carbonyl. Methods Enzymol 1994:233:357-63

31. Kayali R, Cakatay U, Akcay T, Altug T. Effect of alpha-lipoic acid supplementation on markers of protein oxidation in post mitotic tissues of ageing rat. Cell Biochem Funct 2006;24:79-85.

32. Aebi H. Catalase in vitro. Methods Enzymol 1984;105:121-6.

33. Beauchamp C, Fridovich I. Superoxide dismutase: improved assays and an assay applicable to acrylamide gels. Anal Biochem 1971;44:276-87.

34. FloheL, Gunzler WA. Assays of glut athione peroxidase. Methods Enzymol 1984;105:114-21.

35. Ellman GL. Tissue sulfhydryl groups. Arch Biochem Biophys 1959;82:70-7

36. Jollow DJ, Mitchell JR, ZampaglioneN, Gillette JR. Bromobenzeneinduced liver necrosis. Protective role of glutathione and evidence for 3,4-bromobenzene oxide as the hepatotoxic metabolite. Pharmacology 1974;11: 151-69.
37. Jacques-Silva MC, Nogueira CW, Broch LC, Flores EM, Rocha JB Diphenyl diselenide and ascorbic acid changes deposition of selenium and ascorbic acid in liver and brain of mice. Pharm Toxicol 2001;88:11925.

38. Borthiry GR, Antholine WE, Kalyanaraman B, Myres JM, Myres CR Reduction of hexavalent chromium by human cytochrome b5 Generation of hydroxyl radical and superoxide. Free Radic Biol Med 2007;42:738-55.

39. Margetis PI, Antonelou MH, Petropoulos IK, Margaritis LH, Papassideri IS. Increased protein carbonylation of red blood cell membrane in diabetic retinopathy. Exp Mol Pathol 2009;87:76-82.

40. Levine RL. Carbonyl modified proteinsin cellular regulation, aging and disease. Free Radic Biol Med 2002;32:790-6.

41. Balakrishnan R, Satish Kumar CSV, Usha Rani M, Kavita K, Boobalan G, Gopala Reddy A. Evaluation of protective action of $\alpha-$ tocopherol in chromium-inducedoxidative stressin female reproductive system of rats. J Nat Sci Biol Med 2013;4:87-93.

42. Brennan ML, Hazen SL. Amino acid and protein oxidation in cardiovascular disease. Amino Acids 2003;25:365-74.

43. Viswanatha Swamy AHM, Wangikar U, Koti BC, Thippeswamy AHM, Ronad PM, ManjulaDV. Cardioprotective effect of ascorbic acid on dox orubicin-induced myocardial toxicity in rats. Indian J Pharmacol 2011:43:507-11

44. Sroka Z, CisowskiW. Hydrogen peroxide scavenging, antioxidant and anti-radical activity of some phenolic acids. Food Chem Toxicol 2003;41:753-8

45. Mukai K, Nagai S, Ohara K. Kinetic study of the quenching reaction of singlet oxygen by tea catechins in ethanol solution. Free Radical Biol Med 2005;39:752-61.

46. Andjelkovic M, Camp JV, Meulenaer BD, Depaemelaere G, Socaciu C, Verloo M, et al. Iron-chelation properties of phenolic acids bearing catechol and galloyl groups. Food Chem 2006;98:23-31.

47. Mink PJ, Scrafford CG, BarrajLM, Harnack L, Hong CP, Nettleton JA, et al. Flavonoid intake and cardiovascular disease mortality: a prospective study in postmenopausal women. Am J Clin Nutr 2007;85:895-909.

48. Ghosh D, Scheepens A. Vascular action of polyphenols. Mol Nutr Food Res 2009;53:322-31.

49. MorettiE, Mazzi L, Terzuoli G, Bonechi C, Iacoponi F, Martini S, et al. Effect of quercetin, rutin, naringenin and epicatechin on lipid peroxidation induced in human sperm. Reprod Toxicol 2012;34:651-7.

50. Cavia-Saiz M, Busto MD, Pilar-Izquierdo MC, Ortega N, Perez-Mateos $\mathrm{M}$, Muñiz P. Antioxidant properties, radical scavenging activity and biomolecule protection capacity of flavonoid naringenin and its glycoside naringin: a comparative study. J Sci Food Agric 2010;90:123844.

51. Rajadurai M, Prince PS. Preventive effect of naringin on cardiac mitochondrial enzymes during isoproterenol-induced myocardial infarctionin rats: atransmission electron microscopic. J Biochem Mol Toxicol 2007;21:354-61

52. Zaafan MA,Zaki HF, El-Brairy AI, Kenawy SA. Protective effects of atorvastatin andquercetin on isoprenaline-induced myocardial infarction in rats. Bull Fac Pharm Cairo Univ 2013;51:35-41.

53. Arafa HM, Abd-Ellah MF, HafezHF. Abatement by Naringenin of Doxorubicin-Induced Cardiac Toxicity in Rats. J Egypt Natl Canc Inst 2005;17:291-300.

54. Larson AJ, Symons DJ, Jalili T. Therapeutic Potential of Quercetin to Decrease Blood Pressure: Review of Efficacy and Mechanisms. Adv Nutr 2012;3:39-46

55. He F, Zuo L. Redox Roles of Reactive Oxygen Species in Cardiovascular Diseases. Int J Mol Sci 2015, 16, 27770-80.

56. TouyzRM, Schiffrin EL. Reactive oxygen species in vascular biology: implications in hypertension. Histochem Cell Biol 2004;122:339-52. 
57. NojiriH, Shimizu T, Funakoshi M, Yamaguchi O, Zhou H, Kawakami $\mathrm{S}$, et al. Oxidative stress causes heart failure with impaired mitochondrial respiration. J Biol Chem 2006;281:33789-801.

58. Putri H, Nagadi S, Larasati YA, Wulandari N, Hermawan A. Cardioprotective and hepatoprotective effects of Citrus hystrixpeels extract on rats model, Nugroho AE. Asian Pac J Trop Biomed 2013;3:371-5

59. Al-Yahya MA, Mothana RA, Al-Said MS, El-Tahir KE, Al-Sohaibani M, RafatullahS. Citrus medica “Otroj”: Attenuates Oxidative Stress and Cardiac Dysrhythmia in Isoproterenol-Induced Cardiomyopathy in Rats. Nutrients 2013;5:4269-83.

60. Choi BK, Kim TW, Lee DR, Jung WH, Lim JH, Jung JY, et al. A polymethoxy flavonoids-rich Citrus aurantium extract ameliorates ethanol-induced liver injury through modulationof AMPK and Nrf2related signals in a binge drinking mouse model. Phytother Res 2015;29:1577-84.
61. Kim TW, Lee DR, Choi BK, Kang HK, Jung JY, Lim SW, et al. Hepatoprotective effects of polymethox yflavones against acute and chronic carbon tetrachloride intoxication. Food Chem Toxicol 2016;91:91-9.

62. Lim SW, Lee DR, Choi BK, Kim HS, Yang SH, Joo-Won Suh JW, et al. Protective effects of a polymethoxy flavonoids-rich Citrus aurantium peel extract on liver fibrosis induced by bile duct ligationin mice. Asian Pac J Trop Dis 2016;9:1158-64. 